\title{
Effect of combined application of organic and inorganic phosphatic fertilizers on dynamic of microbial biomass in semi-arid soil
}

\author{
Shahab Ahmad Khosa ${ }^{1, *}$, Khalid Saifullah Khan ${ }^{1}$, Muhammad Akmal', \\ Khalid Mehmood Qureshi ${ }^{2}$ \\ 1 PMAS-Arid Agriculture University Rawalpindi, Institute of Soil Science. Shamsabad, Muree road, 46000, Punjab, Pakistan \\ 2 PMAS-Arid Agriculture University Rawalpindi, Department of Horticulture. Shamsabad, Muree road 46000, Punjab, Pakistan \\ * M.Sc (PhD student) Shahab Ahmad Khosa, khosa.shahab@gmail.com
}

\begin{abstract}
Received: January 23, 2019

Accepted: February 6, 2020

Associated editor: J. Wyszkowska

Keywords

Biogenic waste compost

$\mathrm{CO}_{2}$ emission

Farmyard manure

Phosphorus availability

Sugar cane filter cake

A silt loam soil was amended with finely ground biogenic waste compost (BWC with C/N 12), farmyard manure (FYM with C/N 19) and sugar cane filter cake (SFC with C/N 14) mixes with inorganic phosphorus fertilizer and also applied in the form of enriched inorganic phosphorus fertilizer. Each organic amendment was applied at the rate of $0.5 \mathrm{mg} \mathrm{C} \mathrm{g}^{-1}$ soil, and incubation was carried out at $25^{\circ} \mathrm{C}$ and $50 \%$ water holding capacity for a period of 90 days. Soil samples were collected on days 0 , 30,60 and 90 of incubation and analyzed for microbial indices (microbial biomass $\mathrm{C}$ and microbial biomass $\mathrm{P}$ ) by fumigation extraction technique and biochemical (phosphatase and dehydrogenase activity) parameters. The significant increase was recorded in cumulative respiration and microbial indices after application of amendments compared to unamended soil (control) due to the availability of easily decomposable organic carbon and P by organic amendments. Application of all amendments increased MBC, MBP and available P by $13 \%, 28 \%$ and $14 \%$ respectively with greater effect with inorganic P-enriched SFC and FYM followed by BWC. Microbial indices and enzyme activity showed the same temporal pattern with maximum increase on day 0 and $30 . \mathrm{CO}_{2}-\mathrm{C} 24 \mathrm{~h}^{-1}$ emission was also higher in the soils amended with organic sources compared to the unamended soil. It is concluded that use of organic amendments enhanced phosphorus bioavailability by increasing microbial activity and enzymatic activity.
\end{abstract}

\section{Introduction}

Soils of Pakistan are generally deficient in organic matter and available forms of certain major plant nutrients especially phosphorus. Phosphorus is one of the most limiting nutrients for crop production (Maranguit et al., 2017). Despite its wide distribution, phosphorus availability is low in soils due to the formation of precipitates with $\mathrm{Ca}$ and $\mathrm{Mg}$ or fixation with other soil components (Malik et al., 2013). In semi-arid areas of Pakistan, the problem of phosphorus is worst because of high soil $\mathrm{pH}$, calcareous soils, low rainfall and water shortage which results in inefficient use of chemical fertilizers. Maintaining better crop by using organic fertilizer sources is a way to manage nutrient shortage in such areas. Microorganisms are highly sensitive and quick in response to the changes in soil conditions particularly in response to organic amendments. Therefore, soil microbial biomass estimation has been extensively used as a tool in studies on nutrients cycling and crop productivity (Schneider et al., 2016). Soil microbes have the ability to store a substantial amount of $\mathrm{P}$ and then maybe slowly released back to the soil (Docampo et al., 2010). Upon the depletion of available carbon, turnover of microbial biomass starts and the $\mathrm{N}$ and $\mathrm{P}$ contained in microbial biomass become available to plants (Malik et al., 2012). Organic manures addition provides nutrients and additional $\mathrm{C}$ which helps in production of great microbial biomass (Sun et al., 2014). Organic amendments promote the activity of soil enzymes like dehydrogenase and phosphatase which helps in organic matter decomposition and P mineralization (Nie et al., 2013). The effectiveness of organic sources however depends on their concentration and mineralization rate (Zhang et al., 2013). Several studies have referred to the use of organic sources like farmyard manure, biogenic waste compost can increase bioavailability of soil nutrients and enhance the efficiency of chemical fertilizers but the combined use of organic fertilizers with inorganic fertilizers, especially with the technique of enrichment of inorganic $P$ with organic sources, still needs to be explored. The main aim of this study was to under- 
stand the dynamics of microbial biomass, phosphorus availability (Olsen P) and enzyme activity (phosphatase and dehydrogenase) in soils amended with three organic sources (compost, farmyard manure and sugar cane filter cake) when enriched with inorganic phosphorus source.

\section{Materials and methods}

\subsection{Soil collection}

A surface $(0-15 \mathrm{~cm})$ soil sample was collected in bulk from the University Research Farm (URF) Koont, Chakwal, Pakistan (latitude $32^{\circ} 40^{\prime} 4.0836^{\prime \prime} \mathrm{N}$ and longitude $72^{\circ} 30^{\prime} 47.7900^{\prime \prime} \mathrm{E}$ ). The field moist soil was hand-picked to remove straw particles, stones and larger soil animals (earthworms etc.) then passed through a $2 \mathrm{~mm}$ sieve and homogenized. The homogenized soil was pre-incubated for 10 days at $25^{\circ} \mathrm{C}$ after moisture adjustment to $50 \%$ of soil water holding capacity. A subsample of the soil was air dried, ground and homogenized for physico-chemical analysis (Table 1). The particle size distribution was measured by Hydrometer method (Gee and Bauder 1986). Water holding capacity was measured by the preparation of saturated soil paste (Anderson and Ingram, 1993). EC and pH were measured using $1: 2$ soil/water ratio (Peters et al., 2003). Total organic carbon (TOC) was measured by Walkley-Black method (Nelson and Sommers 1982). Soil available P was determined by extracting $0.5 \mathrm{M} \mathrm{NaHCO}_{3}$ with soil at $\mathrm{pH} 8.5$ (Olsen and Sommers 1982). Total $\mathrm{Ca}$ and $\mathrm{Mg}$ were determined after digestion with mixture of $\mathrm{HNO}_{3} / \mathrm{HClO}_{4}$ (2:1) after AAS (Ryan et al., 2001).

Table 1.

Physico-chemical properties of Koont soil (Semi-arid) used in the experiment $(n=3)$.

\begin{tabular}{ll}
\hline Property Texture & Soil Silt loam \\
\hline Sand (\%) & 11.6 \\
Silt (\%) & 52 \\
Clay (\%) & 36.4 \\
WHC (\%) & 27 \\
pH $_{1: 2.5}$ & 8.1 \\
EC $_{1: 2.5}$ dS m ${ }^{-1}$ & 0.12 \\
Organic Carbon (mg g-1) & 4.7 \\
Total N (mg g $\left.{ }^{-1}\right)$ & 0.4 \\
Total P (mg g-1) & 0.58 \\
Total K (mg g-1) & 14.5 \\
Soil available P (mg kg-1) & 2.3 \\
Total Ca (mg g-1) & 0.9 \\
Total Mg (mg g-1) & 9.4 \\
\hline
\end{tabular}

\subsection{Organic materials}

Three organic sources were used in this study including compost, farmyard manure (FYM) and sugar cane filter cake (SFC). Biogenic waste compost (BWC) was collected from compost production unit at PMAS-Arid Agriculture University Rawalpindi, Farmyard manure was collected from commercial FYM selling place and sugar cane filter cake was collected from Sargodha sugar mill, Sargodha, Pakistan. Organic material samples were air dried and sieved. Organic sources ( $0.25 \mathrm{mg} \mathrm{C} \mathrm{g}^{-1}$ soil) were mixed with inorganic P (TSP) $\left(10 \mathrm{mg} \mathrm{P}_{2} \mathrm{O}_{5} / \mathrm{kg}\right.$ soil) and incubated for seven days for enrichment treatments. Organic sources were analysed for following chemical analysis EC and $\mathrm{pH}$ was measured using 1:2 soil/water ratio (Peters et al., 2003). Total organic carbon (TOC) was measured by Walkley-Black method (Nelson and Sommers 1982). Organic materials were digested in $1.2: 1 \mathrm{H}_{2} \mathrm{SO}_{4} / \mathrm{H}_{2} \mathrm{O}_{2}$ at $360^{\circ} \mathrm{C}$ for determination of Total $\mathrm{P}$ and Total $\mathrm{N}$ and were measured by Kjeldahl method (Table 2). The content of heavy metal of organic fertilizers were determined by atomic absorption spectroscopy (AAS) and presented in Table 4.

Table 2.

The chemical compositio $\mathrm{n}$ of compost, farmyard manure and sugar cane filter cake $(n=3)$.

\begin{tabular}{lrrr}
\hline Properties & $\begin{array}{r}\text { Sugar cane } \\
\text { Filter Cake }\end{array}$ & $\begin{array}{r}\text { Farmyard } \\
\text { manure }\end{array}$ & Compost \\
\hline $\mathrm{pH}(1: 2)$ & 7.4 & 6.8 & 8.1 \\
$\mathrm{EC}\left(1: 2 \mathrm{dS} \mathrm{m}^{-1}\right)$ & 15.3 & 9.8 & 12.8 \\
$\mathrm{TOC}\left(\mathrm{g} \mathrm{kg}^{-1}\right)$ & 121.8 & 108.4 & 118.6 \\
Total $\left(\mathrm{g} \mathrm{kg}^{-1}\right)$ & 8.9 & 9.4 & 6.2 \\
Total P $\left(\mathrm{g} \mathrm{kg}^{-1}\right)$ & 4.7 & 4.1 & 3.6 \\
Total K $\left(\mathrm{g} \mathrm{kg}^{-1}\right)$ & 12.8 & 11.3 & 10.3 \\
$\mathrm{Ca}\left(\mathrm{g} \mathrm{kg}^{-1}\right)$ & 81.4 & 72.4 & 65.9 \\
$\mathrm{Mg}\left(\mathrm{g} \mathrm{kg}^{-1}\right)$ & 9.3 & 8.2 & 7.5 \\
Fe $\left(\mathrm{g} \mathrm{kg}^{-1}\right)$ & 15.4 & 13.7 & 12.4 \\
$\mathrm{Mn}\left(\mathrm{mg} \mathrm{kg}^{-1}\right)$ & 412.5 & 367.1 & 334.0 \\
$\mathrm{Zn}\left(\mathrm{mg} \mathrm{kg}^{-1}\right)$ & 389.7 & 346.8 & 315.6 \\
$\mathrm{Cu}\left(\mathrm{mg} \mathrm{kg}^{-1}\right)$ & 278.6 & 247.9 & 225.6 \\
Total C/N & 13.7 & 11.5 & 19.1 \\
Total C/P & 25.9 & 26.4 & 32.9 \\
\hline
\end{tabular}

\subsection{Incubation}

The pre-incubated soil was added to incubation jars at the rate of $600 \mathrm{~g} \mathrm{jar}^{-1}$ on an oven-dry weight basis. Eight treatments were applied as follows: i) control (no amendment), ii) phosphorus fertilizer (TSP) $22.6 \mathrm{mg} / \mathrm{kg}$ of soil iii) compost (4.6 $\mathrm{g} \mathrm{kg}^{-1}$ of soil) with phosphorus fertilizer (iv) farmyard manure $\left(3.8 \mathrm{~g} \mathrm{~kg}^{-1}\right.$ of soil) with phosphorus fertilizer (v) sugar cane filter cake (2.8 $\mathrm{g} \mathrm{kg}^{-1}$ of soil) with phosphorus fertilizer (vi) P-enriched compost (vii) P-enriched farmyard manure (viii) P-enriched sugar cane filter cake. Organic amendments were applied at the rate of $1 \% \mathrm{w} / \mathrm{w}$ basis. The experiment was laid out according to completely randomized design (CRD) with four replications. Soil respiration was measured by trapping the evolved $\mathrm{CO}_{2}$ from each jar during the incubation on day 1, 2, 3, 5, 7, 10 and 14, and after that on a weekly basis until the end of the incubation period. Soil samples were collected on day 0, 30, 60 and 90 from each incubation jar and were analysed for microbial parameters. A glass beaker $\left(100 \mathrm{~cm}^{3}\right)$ containing $20 \mathrm{~cm}^{3} 1 \mathrm{M} \mathrm{NaOH}$ was placed inside each incubation jar to preserve the evolved $\mathrm{CO}_{2}$ from the soil samples to measure 


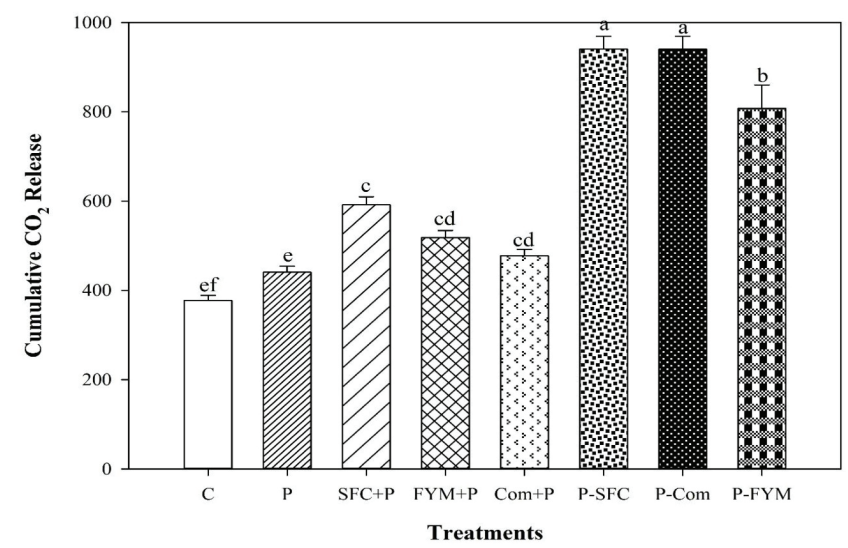

Fig. 1. Cumulative respiration in 90 days $\left(\mathrm{mg} \mathrm{CO}_{2}{ }^{-} \mathrm{C} \mathrm{g}^{-1}\right.$ soil) from soil amended with compost, farmyard manure (FYM) and sugarcane filter cake (SFC) ( $\mathrm{n}=3$ ) C (Control), P (inorganic P fertilizer alone) and P-SFC represents Phosphorus enriched with C, P-FYM represents Phosphorus enriched with FYM and P-Com representing Phosphorus enriched with compost.

$\mathrm{CO}_{2}$ emission by titration and Infrared gas analyser. Microbial biomass carbon (MBC) was measured by using fumigation extraction (Vance et al., 1987), microbial biomass phosphorus (MBP) was determined using fumigation-extraction technique (Joergenson et al., 1995). Soil available phosphorus was measured colorimetrically by $0.5 \mathrm{M} \mathrm{NaHCO}_{3}$ using UV/VIS spectrophotometer at 450 $\mathrm{nm}$ wavelength. The alkaline phosphatase activity was measured by using $p$-nitrophenyl by UV/VIS spectrophotometer at $450 \mathrm{~nm}$ wavelength (Alef, 1995). The dehydrogenase activity (DHA) was evaluated by determination of reduction of 2,3,5-triphenyltetrazolium chloride (TTC) to triphenylformazan (TPF $\mu \mathrm{g} \mathrm{g}^{-1}$ ) by UV/ VIS spectrophotometer at $630 \mathrm{~nm}$ wavelength (Alef, 1995).

\subsection{Statistical analysis}

Cumulative respiration was analysed by one-way ANOVA and rest of the data was analysed by two-way ANOVA. Figures were made using software Sigma plot 12.0. The treatment means were compared by Tukey test at $5 \%$ level of significance.

\section{Results}

\section{$3.1 \mathrm{CO}_{2}$ emission}

Soil respiration is assessed by $\mathrm{CO}_{2}$ emission which results from organic matter decomposition. Thus, soil respiration rate indicates the magnitude of decomposition occurring at a given time in a particular soil. Organic amendments enhanced the $\mathrm{CO}_{2}$ emission from amended soils compared to unamnded soil as biomass of microorganisms increased immediately by the addition of easily decomposable organic $\mathrm{C}$ by the amendments (Kara et al., 2006). Maximum $\mathrm{CO}_{2}$ (32 $\mu \mathrm{g} \mathrm{g}^{-1}$ soil) emission was recorded from the soil treated with P-enriched SFC, which can be explained by the presence of more C in SFC compared to FYM and compost.

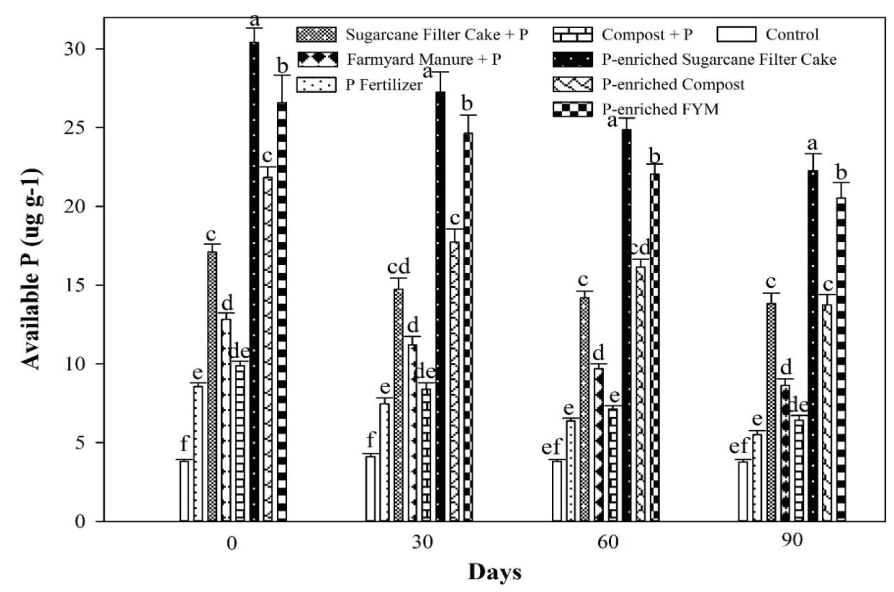

Fig. 2. Soil available P (Olsen P) in 90 days under soil amended with compost, farmyard manure and sugarcane filter cake $(n=3)$.

Cumulative respiration was lowest in unamended control (Fig. 1). Cumulative respiration strongly increased with the addition of organic sources. Highest cumulative respiration was recorded under soil amended with P-enriched SFC and P-enriched Compost. Maximum $\mathrm{CO}_{2}$ released was recorded in the compost amended soil, which can be explained by the presence of strongly decomposable complex of organic molecules in compost (Table 2) (Fig. 1). A positive relation was observed between the soil respiration and $\mathrm{C}$ added by the amendments.

Table 3.

The amount of Organic C, Total $\mathrm{N}$ and Total $\mathrm{P}$ added with amendments at the rate of $0.5 \mathrm{mg} \mathrm{C} \mathrm{g}^{-1}$ soil

\begin{tabular}{lrrr}
\hline Element & $\begin{array}{r}\text { Compost } \\
\left(\mathrm{mg} \mathrm{kg}^{-1} \text { soil }\right)\end{array}$ & $\begin{array}{r}\text { Farmyard } \\
\text { manure } \\
\left(\mathrm{mg} \mathrm{kg}^{-1} \text { soil }\right)\end{array}$ & $\begin{array}{r}\text { Sugarcane filter } \\
\text { cake } \\
\left(\mathrm{mg} \mathrm{kg}^{-1} \text { soil }\right)\end{array}$ \\
\hline Organic C & 1,283 & 1,023 & 1,565 \\
Total N & 67 & 113 & 101 \\
Total P & 37 & 41 & 54 \\
\hline
\end{tabular}

\subsection{Soil available phosphorus}

The content of soil available $\mathrm{P}$ was lowest in unamended control soil and increased with organic and inorganic $\mathrm{P}$ addition rate. Available $\mathrm{P}$ was higher throughout the incubation period in soils amended with compost, farmyard manure and sugar cane filter cake by $14 \%$ compared to P fertilizer alone and unamended soil with maximum increase in soil amended with P-enriched sugar cane filter cake (30.4 $\left.\mu \mathrm{g} \mathrm{g}^{-1}\right)$ at day 0 , which was five to six-fold higher than unamended control (Fig. 2). Available P was highest at day 0 and decreased in all the treatments on day 30,60 and 90, which can be ascribed to P. Decrease microbial uptake of available $\mathrm{P}$ over time and can be due to following reasons: decreased phosphatase activity, organic $P$ pools formation, mineralization of 
organic P and P fixation (Malik et al., 2012). A slight increase in P availability was observed on day 60 in amended soils, which can be attributed to microbial turnover. Throughout the incubation days, maximum $\mathrm{P}$ was recorded in soils amended with P-enriched organic sources, which leads us to conclude that enrichment of inorganic $\mathrm{P}$ with organic $\mathrm{P}$ sources can act as the best source for the constant provision of $\mathrm{P}$.

\subsection{Microbial indices}

In the current study, MBC increased from the very start with the addition of all organic amendments, and the highest increase was recorded in soil amended with P-enriched FYM followed by P-enriched SFC and P-enriched Compost respectively (Fig. 3). The immediate increase was recorded at day 0 in soils amended with organic sources compared to unamended control by $14 \%$ with the maximum in soil amended with P-enriched SFC followed by FYM and Compost. No significant difference was observed in MBC within the organic sources, all of which had strongly enhanced MBC indicating the availability of easily decomposable $C$ in the organic sources. Combination of inorganic $\mathrm{P}$ and organic $\mathrm{P}$ sources stimulated microbial growth.

MBP increased at the start of the incubation and highest value (17.63 $\mu \mathrm{g} \mathrm{g}^{-1}$ ) was recorded on day 30 . This increasing trend and maximum contents of MBP on day 30 can be explained by the addition of more $P$ in the form of inorganic and organic P combined application (Fig. 4). After day 30, a declining trend was recorded, which might be due to the depleting and washing out of these mineralizable substances during the middle and the final days of incubation period. A similar trend of increase and decrease in MBP were reported by (Sinegani and Mahohi, 2009) during the incubation period in soil amended with organic sources. Biomass $C$ and $P$ were lower on day 90 compared to day 0 which represents the microbial turnover that could release nutrients for plant uptake in later phases. All the organic amendments increased MBP by $28 \%$ compared to unamended control with the maximum increase in MBP by soils amended with P-enriched FYM.

\subsection{Enzymatic activity}

In accordance with $\mathrm{CO}_{2}$ emission, the maximum of dehydrogenase activity (DHA) ( $29 \mu \mathrm{g} \mathrm{g}^{-1}$ soil) was at the start of the incubation period and then gradually declined till the end period of incubation (Fig. 5), which indicates the reduction in microbial demand after immediate increase in dehydrogenase activity after amendment addition (Malik et al., 2012). Addition of organic amendments increased the DHA in the soil but the unusual trend was observed by P fertilizer alone and unamended control. Significant dehydrogenase activity was recorded in control compared to soil amended with inorganic P + organic sources. The increase in DHA were higher in soil amended with SFC followed FYM. Unlike other microbial parameters, soil amended with farmyard manure showed the higher DHA in the later stages, which can be due to the presence of more $\mathrm{N}$ contents and less easily mineralizable $\mathrm{N}$ compounds in farmyard manure than in the other two organic amendments. Phosphatase activity was significantly higher throughout the incubation period in all the soils treated with organic amendments compared to unamended control and $\mathrm{P}$ fertilizer alone, with the highest increase in soil treated with P-enriched SFC followed by P-enriched compost and P-enriched FYM respectively (Fig. 6).The highest activity was recorded on day 30 which can be ascribed due to an increase in microbial biomass and $\mathrm{P}$ demand by microbes.

\section{Discussion}

This study confirmed that combined application of organic and inorganic sources enhances soil respiration, microbial biomass, enzyme activity and nutrient availability especially in soil amended with inorganic P-enriched organic sources. P enriched organic sources strongly increased soil respiration at the start of the study and stimulated microbial growth. Organic amendments, particularly SFC and FYM, provided enough nutrients to microbes and contained a higher concentration of nutrients than compost.
Fig. 3. Microbial biomass carbon in 90 days under soil amended with compost, farmyard manure and sugarcane filter cake $(n=3)$.

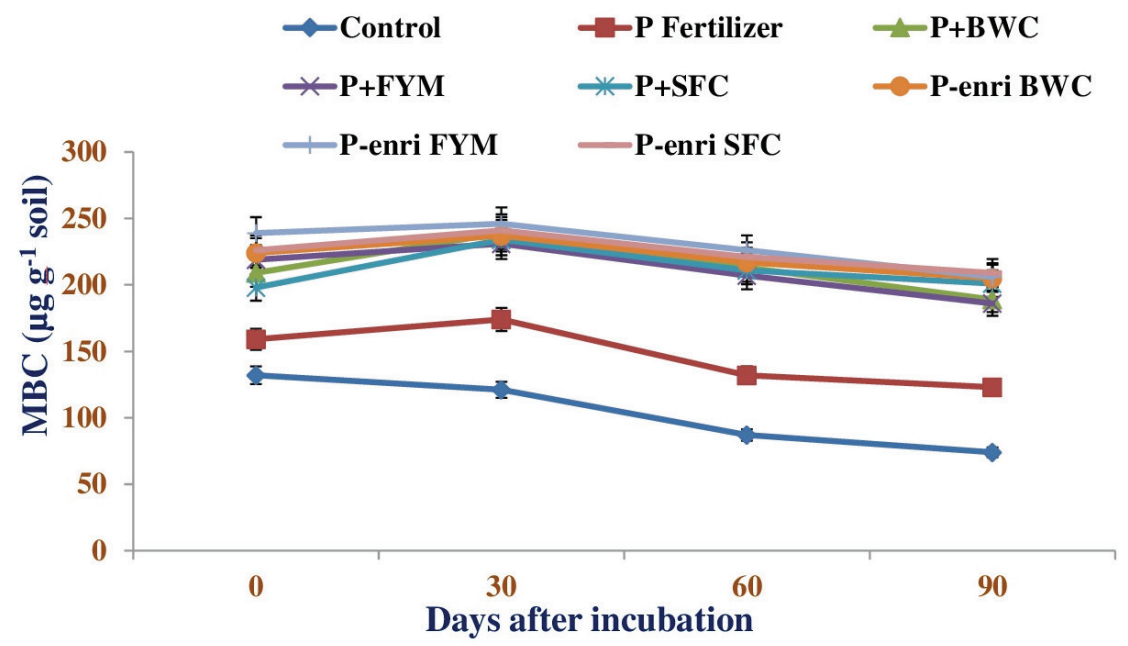


Fig. 4. Microbial biomass phosphorus in 90 days under soil amended with compost, farmyard manure and sugarcane filter cake $(n=3)$.

Fig. 5. Dehydrogenase activity in 90 days under soil amended with compost, farmyard manure and sugarcane filter cake $(n=3)$

Fig. 6. Alkaline phosphatase activity in 90 days under soil amended with compost, farmyard manure and sugarcane filter cake $(n=3)$.
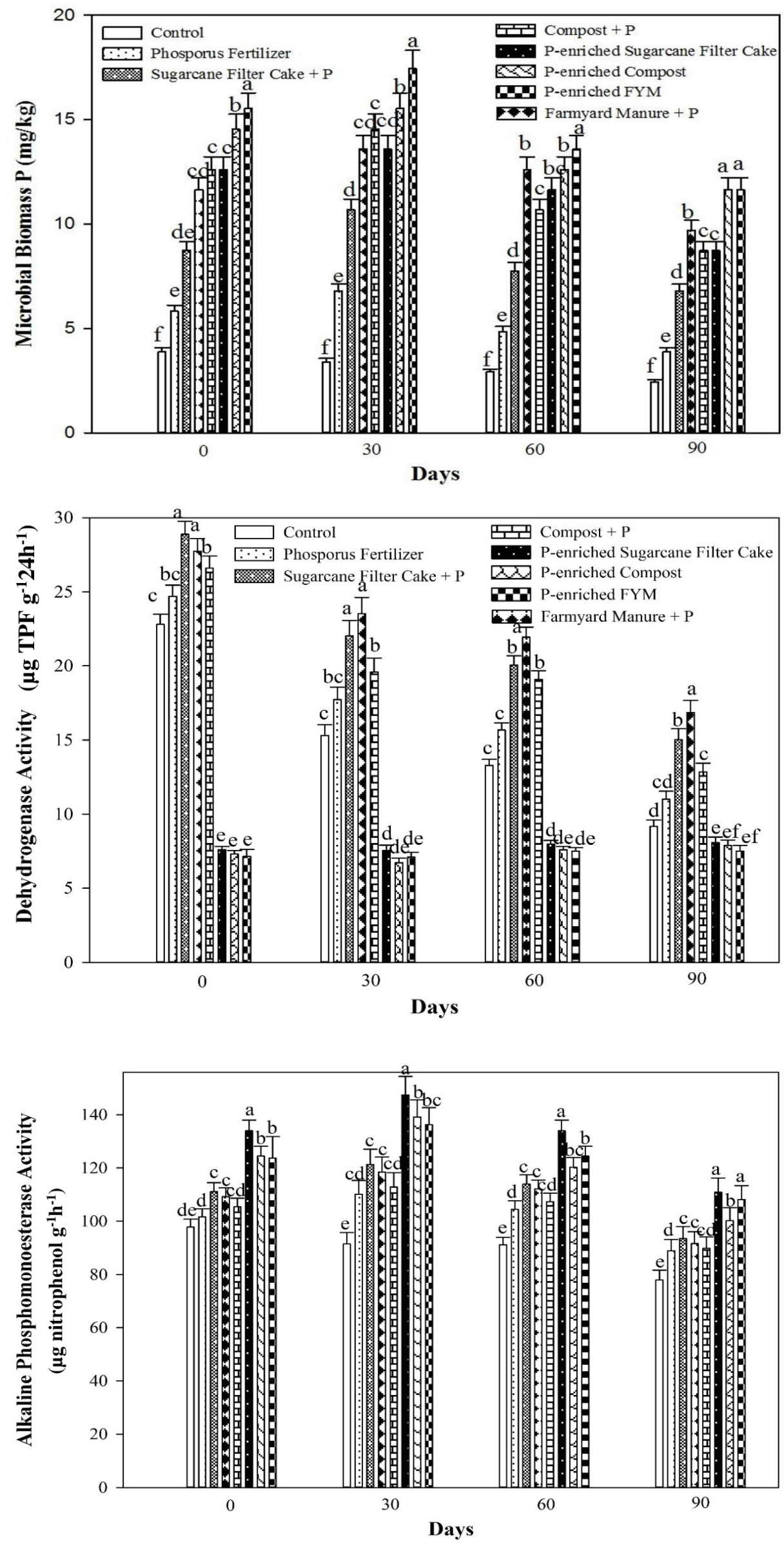


\subsection{Soil respiration and microbial indices}

Soil respiration is the principal mechanism of $\mathrm{C}$ transfer from the soil to the atmosphere and its measurement is the most traditional and popular technique to estimate the microbial activity in soil. The highest respiration rate was recorded during the start of the incubation period in both amended and unamended soils (Fig. 2), which explains the presence of an immense amount of decomposable $\mathrm{C}$. A later decline was observed in $\mathrm{CO}_{2}$ emission in late phases, which may be ascribed to the depletion of those decomposable substances during the second week of incubation period and for the rest of the study (Duong et al., 2009).

Microbial biomass carbon (MBC) has been considered as an estimation of the quantity of the microbial biomass (Bastida et al., 2008) and its estimation has proved very helpful in calculating the changes in microbial biomass in response to variations in soil management techniques (Achat et al., 2010). Increases in microbial biomass carbon after various organic amendments in the soil like farmyard manure, sugar cane filter cake and composts have been reported by several scientists in the past (Marschner et al., 2003; Bohme et al., 2005; Tejada et al., 2006). Lowest MBC was observed in unamended control. Microbial biomass carbon strongly increased after amendments addition with the maximum increase in soil amended with P-enriched SFC and P-enriched FYM followed by BWC amended soil. These findings are in line with (Malik et al., 2013) who also reported the small effect of compost compared to other organic amendments. After day 0 decrease in MBC was observed showing the depletion of available organic $C$ Positive relation was observed between the MBC and organic $\mathrm{C}$ added by the amendments.

The early growth of microbial biomass phosphorus could be due to the $\mathrm{P}$ from the amendments. The increase in MBP might be endorsed by the growth of microbes in response to organic amendments, which resulted in more assimilation of $\mathrm{P}$ into the microbes (Gichangi et al., 2009; Malik et al., 2013). In support to these results, Ayaga et al., (2006) reported increased microbial biomass after organic application to the soil which resulted in more demand for $\mathrm{P}$ and its subsequent incorporation into the microbial biomass or its associated pool of metabolites. Such microbial assimilated $\mathrm{P}$ would be released slowly on microbial turnover that can be taken up by plants.

\subsection{Biochemical Parameters}

Dehydrogenase activity plays a vital role in the decomposition of organic matter and thus is associated with processes of oxidative phosphorylation (Lakhdar et al., 2010). Significant dehydrogenase activity was recorded in control compared to the soil amended with P-enriched organic sources, which may come from the indigenous soil $\mathrm{N}$ and $\mathrm{C}$ or microbes could be $\mathrm{N}$ limited under P-enriched organic amended soils.

Alkaline phosphatase (APA) is believed as an indicator of $\mathrm{P}$ mineralization in the soil as it catalyses the hydrolysis of phosphate from organic monoesters required by the microorganisms and plants to maintain the cellular metabolism (Sinegani and Mahohi, 2009). The highest activity was recorded on day 30, which can be ascribed due to an increase in microbial biomass and increase in microbe $P$ demand. These results are in line with findings of (Sinegani and Mahohi, 2009), who reported the increase in phosphatase activity in response to the organic amendments in soil during the early stages of the incubation period.

\subsection{Organic Amendments}

The stronger effect of organic amendments on the microbial activity, which was measured as soil respiration and enzymatic activity and MBC, can be explained by the supply of easily available nutrients. As the soil was alkaline so $\mathrm{CO}_{2}$ from carbonates can also contribute to $\mathrm{CO}_{2}$ release. Moreover, the fact that amendments had a similar effect on dehydrogenase activity, which is another measure of microbial activity and $\mathrm{CO}_{2}$ suggesting that most of the $\mathrm{CO}_{2}$ measured might came from microbial respiration. SFC and FYM had a significant effect on microbial activity, biomass $C$ and $\mathrm{P}$ and biochemical parameters compared to compost, which can be explained by the presence of higher concentration of nutrients (Total organic carbon, Total N and Total P) in SFC and FYM than (Table 2). Soil amended with compost also increased microbial activity and biomass though to a lesser extent compared to SFC and FYM, which can be ascribed to fewer nutrients and organic material present in compost that is less prone to decomposability than SFC and FYM because, during the process of composting, available organic material was already decomposed and only recalcitrant compounds remained (Wang et al., 2004). In available P, the effect of compost was much lower than SFC and FYM, which can also be explained by the high compost $\mathrm{pH}$ and a very low fraction of total $\mathrm{P}$ present. This makes compost a long-lasting organic material and slow releaser of nutrients.

Table 4.

Heavy metal analysis of organic amendments samples $(n=3)$

\begin{tabular}{|c|c|c|c|c|c|c|c|c|c|}
\hline Sample & $\begin{array}{r}\mathrm{As} \\
\left(\mathrm{mg} \mathrm{kg}^{-1}\right)\end{array}$ & $\begin{array}{r}\mathrm{Cd} \\
\left(\mathrm{mg} \mathrm{kg}^{-1}\right)\end{array}$ & $\begin{array}{r}\text { Co } \\
\left(\mathrm{mg} \mathrm{kg}^{-1}\right)\end{array}$ & $\begin{array}{r}\mathrm{Cr} \\
\left(\mathrm{mg} \mathrm{kg}^{-1}\right)\end{array}$ & $\begin{array}{r}\mathrm{Cu} \\
\left(\mathrm{mg} \mathrm{kg}^{-1}\right)\end{array}$ & $\begin{array}{r}\mathrm{Fe} \\
\left(\mathrm{mg} \mathrm{kg}^{-1}\right)\end{array}$ & $\begin{array}{r}\mathrm{Li} \\
\left(\mathrm{mg} \mathrm{kg}^{-1}\right)\end{array}$ & $\begin{array}{r}\mathrm{Pb} \\
\left(\mathrm{mg} \mathrm{kg}^{-1}\right)\end{array}$ & $\begin{array}{r}\mathrm{Se} \\
\left(\mathrm{mg} \mathrm{kg}^{-1}\right)\end{array}$ \\
\hline Compost & ND & ND & ND & 23.708 & 20.935 & 10277 & 16.49 & ND & ND \\
\hline Farmyard manure & ND & ND & ND & 12.076 & 11.696 & 8033 & 17.78 & ND & ND \\
\hline Sugarcane filter cake & 12.160 & ND & ND & 16.525 & 66.613 & 8352 & 14.09 & ND & 1.503 \\
\hline
\end{tabular}

$\mathrm{ND}=$ Not detected 


\section{Conclusions}

All the organic amendments strongly enhanced soil microbial (soil respiration, MBC, MBP) and biochemical properties (dehydrogenase activity and phosphatase activity) compared to unamended soil, especially the soils treated with inorganic P-enriched organic amendments, which resulted in maximum increase in all the parameters. This leads us to conclude that $\mathrm{P}$ enrichment technique with organic sources could be very useful for stable and constant source of P to soil microbes and plants. Microbial biomass can also release nutrients upon microbial turnover when organic $\mathrm{C}$ gets depleted from amendments. The detailed conclusions are as follows:

Biogenic waste compost and farmyard manure are quick sources of nutrients as they contain easily decomposable compounds compared to sugar cane filter cake as it contains complex organic compounds and high concentration of organic $\mathrm{C}$ and other nutrients.

Generally, soil amended with sugar cane filter cake gave significant results (due to the presence of more organic $\mathrm{C}$ and $\mathrm{P}$ and having low $\mathrm{pH}$ ) in all parameters though farmyard manure and compost also behaved as permanent and stable source soil nutrients for soil microbes. Phosphorus requirement by soil and plant can be accomplished by adding combined organic and inorganic phosphorus sources and due to this we can also reduce the dependence on an inorganic P source to meet the soil and plant $\mathrm{P}$ requirement. For this purpose, inorganic $\mathrm{P}$ enrichment with organic $P$ sources can be the best technique.

\section{Acknowledgement}

Shahab Ahmad Khosa and Khalid Saifullah Khan are highly grateful to Higher Education Commission, Pakistan for providing financial assistance to conduct this study.

\section{References}

Achat, D., Bakker, L.M.R., Morel, C., Augusto, L., Pellerin, S., Gallet-Budynek, A., Gonzalez, M., 2010. Assessing turnover of microbial biomass phosphorus: Combination of an isotopic dilution method with a mass balance model. Soil Biology and Biochemistry 42, 2231-2240. https://doi.org/10.1016/j.soilbio.2010.08.023

Alef, K., 1995. Methods in Applied Soil Microbiology and Biochemistry. Academic Press Inc, San Diego, 228-230.

Ayaga, G., Todd, A., Brookes, P.C., 2006. Enhanced biological cycling of phosphorus increases its availability to crops in low-input sub-Saharan farming systems. Soil Biology and Biochemistry, 38: 81-90. https://doi.org/10.1016/j.soilbio.2005.04.019

Bastida, F., Kandeler, E., Moreno, J.L., Ros M., Garciaan, C., Hernande, T., 2008. Application of fresh and composted organic wastes modifies structure, size and activity of soil microbial community under semiarid climate. Applied Soil Ecology 40, 318-329. https://doi. org/10.1016/j.apsoil.2008.05.007

Bohme, L., Langer, U., Bohme, F., 2005. Microbial biomass, enzyme activities and microbial community structure in two European longterm field experiments. Agriculture Ecosystem and Environment 109, 141-152. https://doi.org/10.1016/j.agee.2005.01.017
Docampo, R., Ulrich, P., Moreno, S.N.J., 2010. Evolution of acidocalcisomes and their role in polyphosphate storage and osmoregulation in eukaryotic microbes. Phil Trans R Soc 365, 775-784. https://doi. org/10.1098/rstb.2009.0179

Duong, T.T.T., Baumann, K., Marschner, P., 2009. Frequent addition of wheat straw residues to soil enhances carbon mineralization rate. Soil Biology and Biochemistry 41, 1475-1482. https://doi.org/10.1016/j. soilbio.2009.04.003

Gee, G.W., Bauder, J.W., 1986. Particle size analysis. In: A. Klute (ed). M Agronomy No.9, Madison, WI, 383-411.

Gichangi, E.M., Mnkeni, P.N.S., Brookes, P.C., 2009. Effects of goat manure and inorganic phosphate addition on soil inorganic and microbial biomass phosphorus fractions under laboratory incubation conditions. Soil Science and Plant Nutrition 55, 764-771. https://doi. org/10.1111/j.1747-0765.2009.00415.x

Joergensen, R.G., Kubler, H., Meyer, B., Wolters, V., 1995. Microbial biomass phosphorus in soils of beech (FagussylvaticaL.) forests. Biology and Fertility of Soils 19, 215-219. https://doi.org/10.1007/BF00336162

Kara, E.E., Uygur, V., Erel, A., 2006. The effects of composted poultry wastes on nitrogen mineralization and biological activity in a silt loam soil. Journal of Applied Science 6 (11), 2476-2480. http://dx.doi. org/10.3923/jas.2006.2476.2480

Lakhdar, A., Scelza, R., Scotti, R., Rao, M.A., Jedidi, N., Gianfreda, L., Abdelly, C., 2010. The effect of compost and sewage sludge on soil biological activities in salt effected soil. R C Suelo Nutr Veg, 10 (1), 40-47. http:// dx.doi.org/10.4067/S0718

Malik, M.A., Khan, K.S., Marschner, P., Ali, S., 2012. Organic amendments differ in their effect on microbial biomass and activity and on P pools in alkaline soils. Biology and Fertility of Soils. https://doi.org/10.1007/ s00374-012-0738-6

Malik, M.A., Khan, K.S., Marshchner, P., Ali, S., 2013. Organic amendments differ in their effect on microbial biomass and activity and on P pools in alkaline soils. Soil Science and Plant Nutrition 49, 415-425. http:// dx.doi.org/10.4067/S0718

Maranguit, D.T., Kuzyakov, Y., 2017. Land-use change affects phosphorus fractions in highly weathered tropical soils. Catena 149, 385-393. http://dx.doi.org/10.1016/j.catena.2017.10

Marschner, P., Kandeler, E., Marschner, B., 2003. Structure and function of the soil microbial community in a long-term fertilizer experiment. Soil Biology and Biochemistry 35, 453-461. https://doi.org/10.1016/ S0038-0717(02)00297-3

Nelson, D.W., Sommers, L.E., 1982. Total carbon, organic carbon and organic matter. In: A.L. Page, R. H. Miller, D. R. Keeney (eds). Methods of Soil Analysis. Part 2: Chemical and microbiological properties.American Society of Agronomy, Madison, WI, 539-579.

Nie, M.E., Pendall, C., Bell, C.K., Gasch, S., Raut, S., Wallenstein, M.D. 2013. Positive climate feedbacks of soil microbial communities in a semi-arid grassland. Ecology Letters 16, 234-241. https://doi.org/10.1111/ ele.12034

Olsen, S.R., Sommers, L.E., 1982. Phosphorus. In: A.L. Page (ed). Methods of soil analysis, Agron No. 9, Part 2: Chemical and microbiological properties, Second Edition. American Society of Agronomy, Madison WI, 403-430.

Peters, J., Combs, S., Hoskins, B., Jarman, J., Kovar, J., Watson, M., Wolf, A., Wolf, N., 2003. Recommended methods for manure analysis. Madison, WI, USA.

Ryan, J., Estefan, G., Rashid, A., 2001. Soil and plant analysis laboratory manual. 2nd edition. Aleppo, Syrian Arab Republic ICARDA.

Schneider, K., Barbara, C.M., Derek, L., Paul, V., 2016. Soil Phosphorus Forms from Organic and Conventional Forage Fields. Soil Science Society of America Journal 10, 2136-2145. https://doi.org/10.2136/sssaj2015.09.0340

Sinegani, A.A.S., Mahohi, A., 2009. Temporal variability of available P, microbial $\mathrm{P}$ and some phosphomonoesterase activities in a sewage sludge treated soil: The effect of soil water potential. African Jour- 
nal of Biotechnology, 8 (24), 6888-6895. https://doi.org/10.4314/ajb. v8i24.66872

Sun, J., Zhang, Q., Zhou, J., Wei, Q., 2014. Pyrosequencing technology reveals the impact of different manure doses on the bacterial community in apple rhizosphere soil. Applied Soil Ecology 78, 28-36. https:// doi.org/10.3390/su9050841

Tajeda, M., Gracia, C., Gonzalez, J.L., Hernandez, M.T., 2006a. Organic amendments based on fresh and composted beet vinasse: Influence on soil properties and wheat yield. Soil Science Society of America 70, 900-908. https://doi.org/10.2136/sssa/j.2005.0271

Tajeda, M., Gracia, C., Gonzalez, J.L., Hernandez, M.T., 2006b. Use of organic amendments as a strategy for saline soil remediation: Influence on the physical, chemical and biological properties of soil. Soil Biology and Biochemistry 38, 1413-1421. https://doi.org/10.1016/j.soilbio.2005.10.017

Vance, E.D., Brookes, P.C., Jenkinson, D.S., 1987. An extraction method for measuring soil microbial biomass C. Soil Biology and Biochemistry 19, 703-707. https://doi.org/10.1016/0038-0717(87)90052-6

Wang, F.E., Chen, Y.X., Tian, G.M., Kumar, S., He, Y.F., Fu, Q.L., Lin, Q., 2009. Microbial biomass carbon, nitrogen and phosphorus in the soil profiles of different vegetation covers established for soil rehabilitation in a red soil region of south-eastern China. Nutrient Cycling in Agroecosystems 68, 181-189. https://doi.org/10.1080/00103620903462332

Zhang, J.S., Wang, Q.,Wang, N., Wang, C., Wang, L., 2013. First determination of $\mathrm{Cu}$ adsorption on soil humin. Environmental Chemistry Letters 11, 41-46. https://doi.org/10.1016/S2095-3119(13)60682-6 